\title{
Bacillus nanhaiensis sp. nov., isolated from an oyster
}

\author{
Yi-Guang Chen, ${ }^{1,2}$ Li Zhang, ${ }^{1}$ Yu-Oin Zhang, ${ }^{3}$ Jian-Wu He, ${ }^{1}$ \\ Hans-Peter Klenk, ${ }^{4}$ Shu-Kun Tang, ${ }^{2}$ You-Xiang Zhang ${ }^{1}$ \\ and Wen-Jun Li $\mathrm{i}^{2,5}$
}

Correspondence

Wen-Jun Li

wjli@ynu.edu.cn

Yi-Guang Chen

mchenjsu@yahoo.com.cn

\author{
${ }^{1}$ College of Biology and Environmental Sciences, Jishou University, Jishou 416000, PR China \\ ${ }^{2}$ The Key Laboratory for Microbial Resources of the Ministry of Education, PR China, and \\ Laboratory for Conservation and Utilization of Bio-Resources, Yunnan Institute of Microbiology, \\ Yunnan University, Kunming 650091, PR China \\ ${ }^{3}$ Institute of Medicinal Biotechnology, Chinese Academy of Medical Sciences \& Peking Union \\ Medical College, Beijing 100050, PR China \\ ${ }^{4}$ Deutsche Sammlung von Mikroorganismen und Zellkulturen, D-38124 Braunschweig, Germany \\ ${ }^{5}$ Guangdong Key Laboratory of Marine Materia Medica, South China Sea Institute of Oceanology, \\ Chinese Academy of Sciences, Guangzhou 510301, PR China
}

Halophilic, halotolerant, alkaliphilic and/or alkalitolerant species of the genus Bacillus are widely distributed throughout various types of saline environments (Ash et al., 1991; Nielsen et al., 1994; Ventosa et al., 1998; Arahal \& Ventosa, 2002; Romano et al., 2005; Lim et al., 2006a, b; Carrasco et al., 2007; Yumoto, 2007; Aino et al., 2008; Chen et al., 2009e; Liu et al., 2009) and these bacteria have attracted increasing interest, attributable to their ability to grow under extreme conditions as well as to the potential use of their enzymes in biotechnological applications (Horikoshi, 1999; Margesin \& Schinner, 2001; Nogi et al., 2005; Krulwich et al., 2007). During an investigation of the diversity of the microbial population of invertebrates

The GenBank/EMBL/DDBJ accession number for the 16S rRNA gene sequence of strain JSM $082006^{\top}$ is GU477780. inhabiting the South China Sea (Chen et al., 2009a, b, c, d, e; Huang et al., 2009; Xiao et al., 2009), a slightly halophilic, facultatively alkaliphilic, endospore-forming, Gram-stain-positive bacterium, designated strain JSM $082006^{\mathrm{T}}$, was isolated from an oyster collected from Naozhou Island, China. Data from the present taxonomic study indicate that this strain represents a novel species of the genus Bacillus.

Strain JSM $082006^{\mathrm{T}}$ was isolated from homogenates of an oyster by plating $1: 10$ serial dilutions of the sample on marine agar 2216 (MA; Difco) cultivated at $30{ }^{\circ} \mathrm{C}$ for 2 weeks. After primary isolation, the strain was purified by repeated streaking and subculturing on nutrient agar (NA; Atlas, 1993) plates (4-5 times) and examining the cultures by light microscopy. The isolate was preserved both on NA slants at $4{ }^{\circ} \mathrm{C}$ and as $20 \%(\mathrm{v} / \mathrm{v})$ glycerol stocks at $-80{ }^{\circ} \mathrm{C}$. 
For comparison, two type strains, Bacillus barbaricus DSM $14730^{\mathrm{T}}$ and Bacillus arsenicus DSM $15822^{\mathrm{T}}$, were obtained from the Deutsche Sammlung von Mikroorganismen und Zellkulturen (DSMZ, Braunschweig, Germany). Unless indicated otherwise, morphological, physiological, molecular and chemotaxonomic studies were performed with cells grown on $\mathrm{NA}\left(\mathrm{pH} \mathrm{8.0)}\right.$ at $30{ }^{\circ} \mathrm{C}$.

Cell morphology was examined by using light microscopy (model DM3000; Leica). Gram staining and the $\mathrm{KOH}$ lysis test were carried out according to Smibert \& Krieg (1994) and Gregersen (1978), respectively. Flagella and endospores were examined according to the methods of Leifson and Schaeffer-Fulton, respectively (Smibert \& Krieg, 1994). Growth was tested at various temperatures $\left(4,5-55{ }^{\circ} \mathrm{C}\right.$, in increments of $\left.5{ }^{\circ} \mathrm{C}\right)$ and $\mathrm{pH}(5.0-11.0$, in increments of 0.5 $\mathrm{pH}$ units) on NA as well as in nutrient broth (NB; Atlas, 1993). Growth in the absence of $\mathrm{NaCl}$ was investigated on NA prepared according to the formula of Atlas (1993) except that $\mathrm{NaCl}$ was excluded. Tolerance of $\mathrm{NaCl}$ was tested on $\mathrm{NA}$ at different $\mathrm{NaCl}$ concentrations [0.1 and $0.5 \%(\mathrm{w} / \mathrm{v})$, and $1-30 \%(\mathrm{w} / \mathrm{v})$, in increments of $1 \%$ ]. Methyl red and Voges-Proskauer tests, determination of $\mathrm{H}_{2} \mathrm{~S}$ production from L-cysteine, hydrolysis of aesculin, indole production, and nitrate and nitrite reduction were tested as recommended by Smibert \& Krieg (1994). Hydrolysis of casein, cellulose, DNA, gelatin, starch, Tweens 20, 40, 60 and 80, and urea was determined as described by Cowan \& Steel (1965). Growth under anaerobic conditions was determined on MA and NA supplemented with $0.5 \%(\mathrm{w} / \mathrm{v})$ glucose and with or without $0.1 \% \quad(\mathrm{w} / \mathrm{v})$ nitrate by using the GasPak Anaerobic System (BBL) according to the manufacturer's instructions. Determination of acid production from carbohydrates and utilization of carbon and nitrogen sources were performed as recommended by Ventosa et al. (1982). Observation of motility and tests for catalase and oxidase activities were carried out as described previously (Chen et al., 2007). Other enzymic activities were assayed by using API ZYM strips (bioMérieux) according to the manufacturer's instructions.

Strain JSM $082006^{\mathrm{T}}$ was slightly halophilic and facultatively alkaliphilic, with optimum growth occurring in $0.5-4.0 \%(\mathrm{w} / \mathrm{v}) \mathrm{NaCl}$ and at $\mathrm{pH}$ 8.0. Colonies were pale yellow-pigmented, flat, translucent with glistening surfaces and circular/slightly irregular margins, and $2-3 \mathrm{~mm}$ in diameter after incubation for $2-3$ days at $30{ }^{\circ} \mathrm{C}$ on NA. Cells were Gram-stain-positive, endospore-forming, motile, aerobic, straight rods. Detailed phenotypic properties that differentiate strain JSM $082006^{\mathrm{T}}$ from related species of the genus Bacillus are summarized in Table 1 and also mentioned in the species description below.

Genomic DNA was isolated according to Hopwood et al. (1985) and the $\mathrm{G}+\mathrm{C}$ content was determined using the HPLC method (Mesbah et al., 1989). The 16S rRNA gene was amplified by PCR and sequenced as described by Cui et al. (2001). Pairwise sequence similarities were calculated using a global alignment algorithm, implemented at the EzTaxon server (Chun et al., 2007). Phylogenetic analysis was performed by using the software package MEGA version 4.1 (Tamura et al., 2007) after multiple alignment of sequence data by CLUSTAL x (Thompson et al., 1997). Distances were calculated using distance options according to Kimura's two-parameter model (Kimura, 1980) and clustering was performed with the neighbour-joining method (Saitou \& Nei, 1987). Maximum-likelihood (Felsenstein, 1981) and maximum-parsimony (Kluge \& Farris, 1969) trees were generated by using the treeing algorithms contained in the PHYLIP package (Felsenstein, 2002). Bootstrap analysis was used to evaluate the tree topology of the neighbour-joining data by means of 1000 resamplings (Felsenstein, 1985). After the DNA was purified to an absorbance ratio $\left(A_{260} / A_{280}\right)$ greater than 1.8, DNA-DNA hybridization experiments were performed using the optical renaturation method (De Ley et al., 1970; Huß et al., 1983; Jahnke, 1992) using a UV-1206 spectrophotometer (Shimadzu) equipped with a TB-85 thermo-bath. Every hybridization experiment was performed with five replications and the highest and lowest values in each experiment were excluded. The DNA-DNA relatedness values were expressed as the means of the remaining three values.

The DNA G + C content of strain JSM $082006^{\mathrm{T}}$ was $40.2 \mathrm{~mol} \%$. The almost-complete $16 \mathrm{~S}$ rRNA gene sequence (1429 bp) was determined. Phylogenetic analysis based on $16 \mathrm{~S}$ rRNA gene sequences revealed that strain JSM $082006^{\mathrm{T}}$ should be assigned to the genus Bacillus and that it was most closely related to the type strains of $B$. barbaricus (16S rRNA gene sequence similarity of $99.1 \%$; Täubel et al., 2003) and B. arsenicus (97.5\%; Shivaji et al., 2005), followed by those of Bacillus rigui (96.6\%; Baik et al., 2010) and Bacillus solisalsi (96.1\%; Liu et al., 2009); sequence similarities observed with other species of the genus Bacillus were less than $96 \%$. The neighbour-joining phylogenetic tree further confirmed that strain JSM $082006^{\mathrm{T}}$ was phylogenetically related closely to species of the genus Bacillus and the isolate formed a robust lineage with the type strains of $B$. barbaricus and B. arsenicus (Fig. 1). The topology was similar to those of phylogenetic trees reconstructed by using maximum-likelihood and maximum-parsimony methods (not shown). Levels of DNADNA relatedness between strain JSM $082006^{\mathrm{T}}$ and the type strains of B. barbaricus and B. arsenicus were $34.1 \%$ (SD of $3.2 \%$ ) and $18.5 \%$ (SD of $2.5 \%$ ), respectively, values that are well below the threshold value $(70 \%)$ recommended by Wayne et al. (1987) for the definition of members of a species. Therefore, it would appear that, on the basis of the phylogenetic and DNA-DNA hybridization data, strain JSM $082006^{\mathrm{T}}$ represents a novel species of the genus Bacillus according to accepted criteria (Wayne et al., 1987; Stackebrandt \& Goebel, 1994).

Amino acids of whole-cell hydrolysates were analysed as described by Hasegawa et al. (1983). Isoprenoid quinones 
Table 1. Characteristics used to distinguish strain JSM $082006^{\top}$ from the type strains of phylogenetically related species of the genus Bacillus

Strains: 1, B. nanhaiensis sp. nov. JSM $082006^{\mathrm{T}}$; 2, B. barbaricus DSM $14730^{\mathrm{T}} ; 3$, B. arsenicus DSM $15822^{\mathrm{T}}$. + , Positive; - , negative. All strains are Gram-stain-positive rods that produce subterminal oval endospores. All strains are positive for catalase activity and hydrolysis of starch, but negative for nitrate and nitrite reduction, $\mathrm{H}_{2} \mathrm{~S}$ and indole production, methyl red and Voges-Proskauer tests, and hydrolysis of cellulose, DNA, Tweens 20, 40 and 60, and urea. All strains produce acid from D-glucose, glycogen and maltose, but not from adonitol, L-arabinose, cellobiose, dulcitol, D-galactose, glycerol, myo-inositol, lactose, D-mannitol, D-mannose, melezitose, melibiose, raffinose, L-rhamnose, D-ribose, D-salicin, Dsorbitol or D-xylose. All strains utilize D-glucose, maltose, dextrin and L-histidine as sole carbon or nitrogen and energy sources, but the following are not utilized: L-arabinose, cellobiose, D-galactose, lactose, melezitose, melibiose, raffinose, L-rhamnose, sucrose, D-xylose, adonitol, D-arabitol, glycerol, D-sorbitol, D-salicin, acetate, butyrate, citrate, propionate, succinate, L-arginine, L-asparagine, L-glutamic acid, glycine, hydroxy-L-proline, L-isoleucine, L-methionine, L-serine and L-valine. Except where marked, all data are from this study.

\begin{tabular}{|c|c|c|c|}
\hline Characteristic & 1 & 2 & 3 \\
\hline Colony colour & Pale yellow & Brownish & Cream \\
\hline Swollen sporangium & - & + & - \\
\hline Motility & + & - & + \\
\hline Oxidase & - & - & + \\
\hline Facultatively anaerobic & - & + & - \\
\hline \multicolumn{4}{|l|}{ Growth in $\mathrm{NaCl}(\mathrm{w} / \mathrm{v})$ : } \\
\hline $2 \%$ & + & - & + \\
\hline $18 \%$ & + & - & - \\
\hline \multicolumn{4}{|l|}{ Growth at: } \\
\hline $15^{\circ} \mathrm{C}$ & + & - & - \\
\hline pH 10.5 & + & + & - \\
\hline \multicolumn{4}{|l|}{ Hydrolysis of: } \\
\hline Aesculin & + & + & - \\
\hline Casein & - & + & - \\
\hline Gelatin & + & - & + \\
\hline Tween 80 & - & - & + \\
\hline \multicolumn{4}{|l|}{ Acid production from: } \\
\hline$N$-Acetylglucosamine & - & + & - \\
\hline D-Fructose & - & + & - \\
\hline Starch & + & + & - \\
\hline Sucrose & + & - & + \\
\hline Trehalose & - & + & - \\
\hline \multicolumn{4}{|l|}{ Utilization of: } \\
\hline D-Fructose & - & + & + \\
\hline Trehalose & - & + & + \\
\hline myo-Inositol & - & - & + \\
\hline Gluconate & - & + & - \\
\hline D-Mannose & - & + & - \\
\hline D-Mannitol & + & - & + \\
\hline D-Ribose & - & + & - \\
\hline L-Alanine & + & + & - \\
\hline L-Leucine & - & + & - \\
\hline L-Phenylalanine & - & + & - \\
\hline L-Proline & - & + & - \\
\hline DNA G $+\mathrm{C}$ content $(\mathrm{mol} \%)$ & 40.2 & $42.0^{*}$ & $35.0 \dagger$ \\
\hline
\end{tabular}

${ }^{\star}$ Data from Baik et al. (2010).

$\dagger$ Data from Shivaji et al. (2005).

were analysed by HPLC as described by Groth et al. (1996). Polar lipids were extracted according to the method of Minnikin et al. (1979) and were identified by twodimensional TLC and spraying with the appropriate detection reagents (Collins \& Jones, 1980). Fatty acids in the isolate and B. barbaricus DSM $14730^{\mathrm{T}}$ were determined according to Sasser (1990) using the Microbial Identification System (Microbial ID) with cells grown in $\mathrm{NB}(\mathrm{pH} 8.0$; Atlas, 1993) in flasks on a rotary shaker (with shaking at 200 r.p.m.) at $30{ }^{\circ} \mathrm{C}$ for 2 days. 


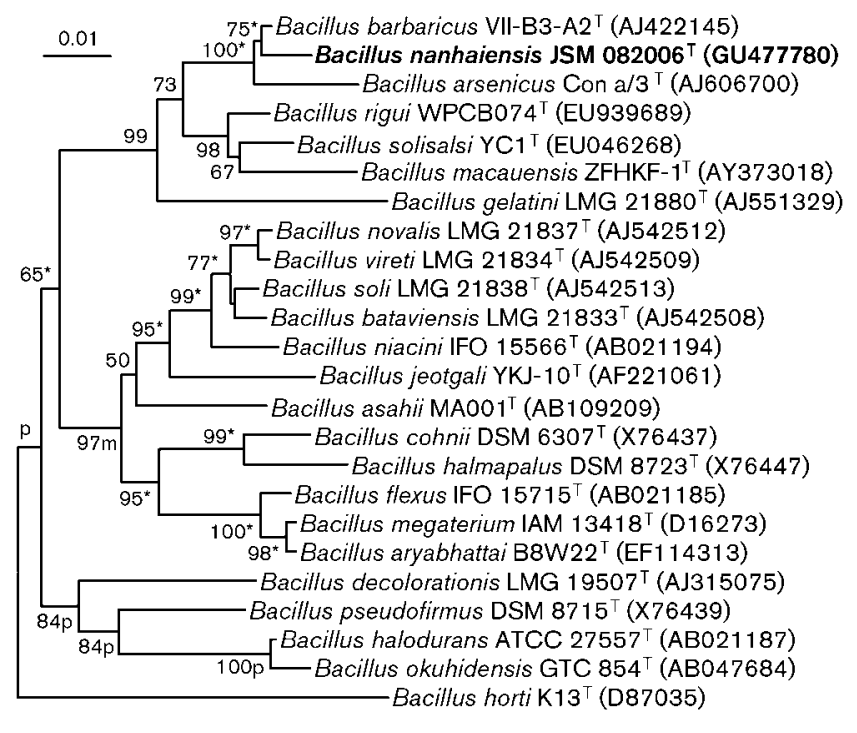

Fig. 1. Phylogenetic tree showing the phylogenetic positions of strain JSM $082006^{\top}$ and related taxa based on 16S rRNA gene sequence analysis reconstructed by using the neighbour-joining method. ' $m$ ' or ' $p$ ' labels indicate branches that were also found with the maximum-likelihood (Felsenstein, 1981) or maximumparsimony (Kluge \& Farris, 1969) algorithms, respectively; asterisks indicate branches that were recovered with all three methods. Numbers at nodes are bootstrap percentages (>50\%) based on a neighbour-joining analysis of 1000 resampled datasets. Bar, 1 substitution per 100 nt.

Chemotaxonomic data for strain JSM $082006^{\mathrm{T}}$ were consistent with assignment of the strain to the genus Bacillus. The strain possessed a cell-wall type based on meso-diaminopimelic acid. Strain JSM $082006^{\mathrm{T}}$ contained MK-7 (95.1\%) as the predominant menaquinone, with MK-8 (4.1\%) and MK-6 (0.8\%) present in minor amounts. Diphosphatidylglycerol, phosphatidylglycerol and phosphatidylethanolamine were predominant in the polar lipid profile; an unknown aminophospholipid, an unknown phospholipid and an unknown polar lipid were also detected. The fatty acid profile of strain JSM $082006^{\mathrm{T}}$ was similar to that of B. barbaricus DSM $14730^{\mathrm{T}}$, although there were differences in the proportions of some components (Table 2). Major fatty acids $(>10 \%$ of the total) of strain JSM $082006^{\mathrm{T}}$ were anteiso- $\mathrm{C}_{15: 0}(40.7 \%)$, iso- $\mathrm{C}_{15: 0}(17.8 \%)$ and $\mathrm{C}_{16: 0}(14.0 \%)$.

The results of the phylogenetic analysis, and morphological and chemotaxonomic investigations support the affiliation of strain JSM $082006^{\mathrm{T}}$ to the genus Bacillus. However, the pale yellow pigmentation of strain JSM $082006^{\mathrm{T}}$, as well as the ability to tolerate up to $18 \%(\mathrm{w} / \mathrm{v}) \mathrm{NaCl}$ and grow at $15{ }^{\circ} \mathrm{C}$, clearly differentiated the isolate from its phylogenetic relatives B. barbaricus and B. arsenicus (Table 1). The presence of noticeable amounts of unbranched saturated fatty acids (making up $19.2 \%$ of the total) and the absence of $\mathrm{C}_{16: 1} \omega 7 c$ in the fatty acid profile of strain JSM $082006^{\mathrm{T}}$
(Table 2), together with several other phenotypic characteristics (Table 1), also differentiated the novel strain clearly from $B$. barbaricus, its closest phylogenetic relative. In conclusion, phylogenetic analysis based on 16S rRNA gene sequences, DNA-DNA relatedness results, and the phenotypic and chemotaxonomic data presented here support the proposal that strain JSM $082006^{\mathrm{T}}$ represents a novel species of the genus Bacillus, for which the name Bacillus nanhaiensis sp. nov. is proposed.

\section{Description of Bacillus nanhaiensis sp. nov.}

Bacillus nanhaiensis (nan.hai.en'sis. N.L. masc. adj. nanhaiensis pertaining to Nanhai, the Chinese name for the South China Sea, the source of the sample from which the type strain was isolated).

Cells are Gram-stain-positive, catalase-positive, oxidasenegative, aerobic, straight rods, approximately $0.4-0.6 \mu \mathrm{m}$ wide and 4.0-6.0 $\mu \mathrm{m}$ long, occurring singly, as pairs or as short chains, producing oval endospores that lie in subterminal unswollen sporangia. Motile by means of a single polar flagellum. Colonies are pale yellow-pigmented, flat and translucent, have glistening surfaces and circular/ slightly irregular margins, and are $2-3 \mathrm{~mm}$ in diameter on NA. No diffusible pigments are produced. Slightly halophilic and facultatively alkaliphilic; growth occurs in $0-18 \%(\mathrm{w} / \mathrm{v}) \mathrm{NaCl}$ (optimum $0.5-4.0 \%$ ), at $\mathrm{pH} 6.0-10.5$ (optimum $\mathrm{pH} 8.0$ ) and at $15-45{ }^{\circ} \mathrm{C}$ (optimum $30{ }^{\circ} \mathrm{C}$ ). Nitrate and nitrite are not reduced. Negative for methyl red, Voges-Proskauer, $\mathrm{H}_{2} \mathrm{~S}$ and indole production tests. Aesculin, gelatin and starch are hydrolysed, but casein, cellulose, DNA, Tweens 20, 40, 60 and 80, and urea are not. Acids are produced from D-glucose, glycogen, maltose, starch and sucrose, but not from $\mathrm{N}$-acetylglucosamine, adonitol, L-arabinose, cellobiose, dulcitol, D-fructose, Dgalactose, glycerol, myo-inositol, lactose, D-mannitol, Dmannose, melezitose, melibiose, raffinose, L-rhamnose, Dribose, D-salicin, D-sorbitol, trehalose or D-xylose. DGlucose, maltose, dextrin, D-mannitol, L-alanine and Lhistidine are utilized as sole sources of carbon and energy or sole sources of carbon, nitrogen and energy; L-arabinose, cellobiose, D-fructose, D-galactose, lactose, D-mannose, melezitose, melibiose, raffinose, L-rhamnose, D-ribose, sucrose, trehalose, D-xylose, adonitol, D-arabitol, glycerol, myo-inositol, D-sorbitol, D-salicin, acetate, butyrate, citrate, gluconate, propionate, succinate, L-arginine, L-asparagine, L-glutamic acid, glycine, hydroxy-L-proline, L-isoleucine, Lleucine, L-methionine, L-phenylalanine, L-proline, L-serine and L-valine are not utilized. Constitutive enzymes expressed are acid phosphatase, alkaline phosphatase, esterase (C4) and esterase lipase (C8); $\alpha$-chymotrypsin, cystine arylamidase, $\alpha$-fucosidase, $\alpha$ - and $\beta$-galactosidase, $\alpha$ - and $\beta$-glucosidase, $N$-acetyl- $\beta$-glucosaminidase, $\beta$-glucuronidase, leucine arylamidase, lipase (C14), $\alpha$-mannosidase, naphthol-AS-BI-phosphohydrolase, trypsin and valine arylamidase activities are not observed. mesoDiaminopimelic acid is present in the cell-wall peptidoglycan as the diagnostic diamino acid. Possesses MK-7 as the 
Table 2. Fatty acid composition of strain JSM $082006^{\top}$ and Bacillus barbaricus DSM $14730^{\top}$

Strains: 1, B. nanhaiensis sp. nov. JSM $082006^{\mathrm{T}} ; 2$, B. barbaricus DSM $14730^{\mathrm{T}}$. Data are percentages of the total fatty acid content; fatty acids representing $<0.5 \%$ in both strains have been omitted. -, Not detected. All data are from this study.

\begin{tabular}{|c|c|c|}
\hline Fatty acid & 1 & 2 \\
\hline \multicolumn{3}{|l|}{ Saturated } \\
\hline $\mathrm{C}_{14: 0}$ & 2.8 & 0.8 \\
\hline $\mathrm{C}_{16: 0}$ & 14.0 & 3.5 \\
\hline $\mathrm{C}_{16: 0} \mathrm{~N}$ alcohol & 1.8 & 0.6 \\
\hline $\mathrm{C}_{17: 0}$ & 0.6 & - \\
\hline \multicolumn{3}{|l|}{ Unsaturated } \\
\hline $\mathrm{C}_{16: 1} \omega 7 c$ alcohol & 0.6 & 1.0 \\
\hline $\mathrm{C}_{16: 1} \omega 7 c$ & - & 6.5 \\
\hline $\mathrm{C}_{16: 1} \omega 11 c$ & 1.5 & 7.1 \\
\hline $\mathrm{C}_{18: 1} \omega 9 c$ & 0.8 & 0.2 \\
\hline \multicolumn{3}{|l|}{ Branched } \\
\hline iso- $\mathrm{C}_{14: 0}$ & 7.2 & 5.2 \\
\hline iso- $\mathrm{C}_{15: 0}$ & 17.8 & 18.1 \\
\hline anteiso- $\mathrm{C}_{15: 0}$ & 40.7 & 46.2 \\
\hline iso- $\mathrm{C}_{16: 0}$ & 4.6 & 2.3 \\
\hline iso- $\mathrm{C}_{17: 0}$ & 1.1 & 1.6 \\
\hline anteiso- $\mathrm{C}_{17: 0}$ & 2.5 & 4.5 \\
\hline Summed feature $3^{*}$ & 1.3 & - \\
\hline Summed feature $4^{*}$ & 0.5 & 1.6 \\
\hline
\end{tabular}

${ }^{\star}$ Summed features represent groups of two or three fatty acids that cannot be separated by GLC with the MIDI system. Summed feature 3 comprises $\mathrm{C}_{16: 1} \omega 7 c$ and/or $\mathrm{C}_{16: 1} \omega 6 c$. Summed feature 4 comprises iso- $\mathrm{C}_{17: 1} \mathrm{I}$ and/or anteiso- $\mathrm{C}_{17: 1} \mathrm{~B}$.

predominant menaquinone and diphosphatidylglycerol, phosphatidylglycerol and phosphatidylethanolamine as the predominant polar lipids. Major fatty acids $(>10 \%$ of the total) are anteiso- $\mathrm{C}_{15: 0}$, iso- $\mathrm{C}_{15: 0}$ and $\mathrm{C}_{16: 0}$.

The type strain is JSM $082006^{\mathrm{T}}\left(=\mathrm{DSM} 23009^{\mathrm{T}}=\mathrm{KCTC}\right.$ $13712^{\mathrm{T}}$ ), isolated from homogenates of an oyster collected from Naozhou Island in the South China Sea, China. The DNA G + C content of the type strain is $40.2 \mathrm{~mol} \%$ (HPLC method).

\section{Acknowledgements}

This work was supported by grants from the National Basic Research Program of China (2010CB833800), National Natural Science Foundation of China (NSFC) (30970007) and International Cooperation Research Program of Yunnan Province (2009AC017). We are grateful to $\mathrm{Mr} \mathrm{Ke}$ Huang for his excellent technical assistance.

\section{References}

Aino, K., Hirota, K., Matsuno, T., Morita, N., Nodasaka, Y., Fujiwara, T., Matsuyama, H., Yoshimune, K. \& Yumoto, I. (2008). Bacillus polygoni sp. nov., a moderately halophilic, non-motile obligate alkaliphile isolated from indigo balls. Int J Syst Evol Microbiol 58, 120-124.

Arahal, D. R. \& Ventosa, A. (2002). Moderately halophilic and halotolerant species of Bacillus and related genera. In Applications and Systematics of Bacillus and Relatives, pp. 83-99. Edited by R. C. W. Berkeley, M. Heyndrickx, N. Logan \& P. De Vos. Oxford: Blackwell.

Ash, C., Farrow, J. A. E., Wallbanks, S. \& Collins, M. D. (1991). Phylogenetic heterogeneity of the genus Bacillus as revealed by comparative analysis of small-subunit ribosomal-RNA sequences. Lett Appl Microbiol 13, 202-206.

Atlas, R. M. (1993). Handbook of Microbiological Media. Edited by L. C. Parks. Boca Raton, FL: CRC Press.

Baik, K. S., Lim, C. H., Park, S. C., Kim, E. M., Rhee, M. S. \& Seong, C. N. (2010). Bacillus rigui sp. nov., isolated from wetland freshwater. Int J Syst Evol Microbiol 60, 2204-2209.

Carrasco, I. J., Márquez, M. C., Xue, Y., Ma, Y., Cowan, D. A., Jones, B. E., Grant, W. D. \& Ventosa, A. (2007). Bacillus chagannorensis sp. nov., a moderate halophile from a soda lake in Inner Mongolia, China. Int J Syst Evol Microbiol 57, 2084-2088.

Chen, Y.-G., Cui, X.-L., Pukall, R., Li, H.-M., Yang, Y.-L., Xu, L.-H., Wen, M.-L., Peng, Q. \& Jiang, C.-L. (2007). Salinicoccus kunmingensis sp. nov., a moderately halophilic bacterium isolated from a salt mine in Yunnan, south-west China. Int J Syst Evol Microbiol 57, 2327-2332.

Chen, Y.-G., Zhang, Y.-Q., Shi, J.-X., Xiao, H.-D., Tang, S.-K., Liu, Z.-X., Huang, K., Cui, X.-L. \& Li, W.-J. (2009a). Jeotgalicoccus marinus sp. nov., a marine bacterium isolated from a sea urchin. Int J Syst Evol Microbiol 59, 1625-1629.

Chen, Y.-G., Zhang, Y.-Q., Xiao, H.-D., Liu, Z.-X., Yi, L.-B., Shi, J.-X., Zhi, X.-Y., Cui, X.-L. \& Li, W.-J. (2009b). Pontibacillus halophilus sp. nov., a moderately halophilic bacterium isolated from a sea urchin. Int J Syst Evol Microbiol 59, 1635-1639.

Chen, Y.-G., Wang, Y.-X., Zhang, Y.-Q., Tang, S.-K., Liu, Z.-X., Xiao, H.-D., Xu, L.-H., Cui, X.-L. \& Li, W.-J. (2009c). Nocardiopsis litoralis sp. nov., a halophilic marine actinomycete isolated from a sea anemone. Int J Syst Evol Microbiol 59, 2708-2713.

Chen, Y.-G., Zhang, Y.-Q., Huang, H.-Y., Klenk, H.-P., Tang, S.-K., Huang, K., Chen, Q.-H., Cui, X.-L. \& Li, W.-J. (2009d). Halomonas zhanjiangensis sp. nov., a halophilic bacterium isolated from a sea urchin. Int J Syst Evol Microbiol 59, 2888-2893.

Chen, Y.-G., Zhang, Y.-O., Wang, Y.-X., Liu, Z.-X., Klenk, H.-P., Xiao, H.-D., Tang, S.-K., Cui, X.-L. \& Li, W.-J. (2009e). Bacillus neizhouensis sp. nov., a halophilic marine bacterium isolated from a sea anemone. Int J Syst Evol Microbiol 59, 3035-3039.

Chun, J., Lee, J.-H., Jung, Y., Kim, M., Kim, S., Kim, B. K. \& Lim, Y.-W. (2007). EzTaxon: a web-based tool for the identification of prokaryotes based on $16 \mathrm{~S}$ ribosomal RNA gene sequences. Int J Syst Evol Microbiol 57, 2259-2261.

Collins, M. D. \& Jones, D. (1980). Lipids in the classification and identification of coryneform bacteria containing peptidoglycans based on 2,4-diaminobutyric acid. J Appl Bacteriol 48, 459-470.

Cowan, S. T. \& Steel, K. J. (1965). Manual for the Identification of Medical Bacteria. London: Cambridge University Press.

Cui, X.-L., Mao, P.-H., Zeng, M., Li, W.-J., Zhang, L.-P., Xu, L.-H. \& Jiang, C.-L. (2001). Streptimonospora salina gen. nov., sp. nov., a new member of the family Nocardiopsaceae. Int J Syst Evol Microbiol 51, 357-363.

De Ley, J., Cattoir, H. \& Reynaerts, A. (1970). The quantitative measurement of DNA hybridization from renaturation rates. Eur J Biochem 12, 133-142.

Felsenstein, J. (1981). Evolutionary trees from DNA sequences: a maximum likelihood approach. J Mol Evol 17, 368-376. 
Felsenstein, J. (1985). Confidence limits on phylogenies: an approach using the bootstrap. Evolution 39, 783-791.

Felsenstein, J. (2002). PHYLIP (phylogeny inference package), version 3.6a. Distributed by the author. Department of Genome Sciences, University of Washington, Seattle, USA.

Gregersen, T. (1978). Rapid method for distinction of Gram-negative from Gram-positive bacteria. Eur J Appl Microbiol Biotechnol 5, 123 127.

Groth, I., Schumann, P., Weiss, N., Martin, K. \& Rainey, F. A. (1996). Agrococcus jenensis gen. nov., sp. nov., a new genus of actinomycetes with diaminobutyric acid in the cell wall. Int J Syst Bacteriol 46, 234239.

Hasegawa, T., Takizawa, M. \& Tanida, S. (1983). A rapid analysis for chemical grouping of aerobic actinomycetes. J Gen Appl Microbiol 29, 319-322.

Hopwood, D. A., Bibb, M. J., Chater, K. F., Kieser, T., Bruton, C. J., Kieser, H. M., Lydiate, D. J., Smith, C. P., Ward, J. M. \& Schrempf, H. (editors) (1985). Genetic Manipulation of Streptomyces. A Laboratory Manual. Norwich: John Innes Foundation.

Horikoshi, K. (1999). Alkaliphiles: some applications of their products for biotechnology. Microbiol Mol Biol Rev 63, 735-750.

Huang, K., Zhang, L., Liu, Z., Chen, O., Peng, Q., Li, W., Cui, X. \& Chen, Y. (2009). [Diversity of culturable bacteria associated with the sea urchin Hemicentrotus pulcherrimus from Naozhou Island]. Wei Sheng Wu Xue Bao 49, 1424-1429 (in Chinese).

Huß, V. A. R., Festl, H. \& Schleifer, K. H. (1983). Studies on the spectrophotometric determination of DNA hybridization from renaturation rates. Syst Appl Microbiol 4, 184-192.

Jahnke, K. D. (1992). BASIC computer program for evaluation of spectroscopic DNA renaturation data from GILFORD SYSTEM 2600 spectrophotometer on a PC/XT/AT type personal computer. J Microbiol Methods 15, 61-73.

Kimura, M. (1980). A simple method for estimating evolutionary rates of base substitutions through comparative studies of nucleotide sequences. J Mol Evol 16, 111-120.

Kluge, A. G. \& Farris, F. S. (1969). Quantitative phyletics and the evolution of anurans. Syst Zool 18, 1-32.

Krulwich, T. A., Hicks, D. B., Swartz, T. H. \& Ito, M. (2007). Bioenergetic adaptations that support alkaliphily. In Physiology and Biochemistry of Extremophiles, pp. 311-329. Edited by C. Gerday \& N. Glansdorff. Washington, DC: American Society for Microbiology.

Lim, J.-M., Jeon, C. O. \& Kim, C.-J. (2006a). Bacillus taeanensis sp. nov., a halophilic Gram-positive bacterium from a solar saltern in Korea. Int J Syst Evol Microbiol 56, 2903-2908.

Lim, J.-M., Jeon, C. O., Lee, S.-M., Lee, J. C., Xu, L. H., Jiang, C. L. \& Kim, C. J. (2006b). Bacillus salarius sp. nov., a halophilic, sporeforming bacterium isolated from a salt lake in China. Int J Syst Evol Microbiol 56, 373-377.

Liu, H., Zhou, Y., Liu, R., Zhang, K.-Y. \& Lai, R. (2009). Bacillus solisalsi sp. nov., a halotolerant, alkaliphilic bacterium isolated from soil around a salt lake. Int J Syst Evol Microbiol 59, 1460-1464.

Margesin, R. \& Schinner, F. (2001). Potential of halotolerant and halophilic microorganisms for biotechnology. Extremophiles 5, 73-83.

Mesbah, M., Premachandran, U. \& Whitman, W. B. (1989). Precise measurement of the $\mathrm{G}+\mathrm{C}$ content of deoxyribonucleic acid by highperformance liquid chromatography. Int J Syst Bacteriol 39, 159-167.
Minnikin, D. E., Collins, M. D. \& Goodfellow, M. (1979). Fatty acid and polar lipid composition in the classification of Cellulomonas, Oerskovia and related taxa. J Appl Microbiol 47, 87-95.

Nielsen, P., Rainey, F. A., Outtrup, H., Priest, F. G. \& Fritze, D. (1994). Comparative $16 \mathrm{~S}$ rDNA sequence analysis of some alkaliphilic bacilli and the establishment of a sixth rRNA group within the genus Bacillus. FEMS Microbiol Lett 117, 61-65.

Nogi, Y., Takami, H. \& Horikoshi, K. (2005). Characterization of alkaliphilic Bacillus strains used in industry: proposal of five novel species. Int J Syst Evol Microbiol 55, 2309-2315.

Romano, I., Lama, L., Nicolaus, B., Gambacorta, A. \& Giordano, A. (2005). Bacillus saliphilus sp. nov., isolated from a mineral pool in Campania, Italy. Int J Syst Evol Microbiol 55, 159-163.

Saitou, N. \& Nei, M. (1987). The neighbor-joining method: a new method for reconstructing phylogenetic trees. Mol Biol Evol 4, 406425.

Sasser, M. (1990). Identification of bacteria by gas chromatography of cellular fatty acids, MIDI Technical Note 101. Newark, DE: MIDI Inc.

Shivaji, S., Suresh, K., Chaturvedi, P., Dube, S. \& Sengupta, S. (2005). Bacillus arsenicus sp. nov., an arsenic-resistant bacterium isolated from a siderite concretion in West Bengal, India. Int J Syst Evol Microbiol 55, 1123-1127.

Smibert, R. M. \& Krieg, N. R. (1994). Phenotypic characterization. In Methods for General and Molecular Bacteriology, pp. 607-654. Edited by P. Gerhardt, R. G. E. Murray, W. A. Wood \& N. R. Krieg. Washington, DC: American Society for Microbiology.

Stackebrandt, E. \& Goebel, B. M. (1994). Taxonomic note: a place for DNA-DNA reassociation and 16S rRNA sequence analysis in the present species definition in bacteriology. Int J Syst Bacteriol 44, 846849.

Tamura, K., Dudley, J., Nei, M. \& Kumar, S. (2007). MEGA4: molecular evolutionary genetics analysis (MEGA) software version 4.0. Mol Biol Evol 24, 1596-1599.

Täubel, M., Kämpfer, P., Buczolits, S., Lubitz, W. \& Busse, H.-J. (2003). Bacillus barbaricus sp. nov., isolated from an experimental wall painting. Int J Syst Evol Microbiol 53, 725-730.

Thompson, J. D., Gibson, T. J., Plewniak, F., Jeanmougin, F. \& Higgins, D. G. (1997). The CLUSTAL_X windows interface: flexible strategies for multiple sequence alignment aided by quality analysis tools. Nucleic Acids Res 25, 4876-4882.

Ventosa, A., Quesada, E., Rodriguez-Valera, F., Ruiz-Berraquero, F. \& Ramos-Cormenzana, A. (1982). Numerical taxonomy of moderately halophilic Gram-negative rods. J Gen Microbiol 128, 1959-1968.

Ventosa, A., Nieto, J. J. \& Oren, A. (1998). Biology of moderately halophilic aerobic bacteria. Microbiol Mol Biol Rev 62, 504-544.

Wayne, L. G., Brenner, D. J., Colwell, R. R., Grimont, P. A. D., Kandler, O., Krichevsky, M. I., Moore, L. H., Moore, W. E. C., Murray, R. G. E. \& other authors (1987). International Committee on Systematic Bacteriology. Report of the ad hoc committee on reconciliation of approaches to bacterial systematics. Int J Syst Bacteriol 37, 463-464.

Xiao, H.-D., Chen, Y.-G., Liu, Z.-X., Huang, K., Li, W.-J., Cui, X.-L., Zhang, L. \& Yi, L.-B. (2009). [Phylogenetic diversity of cultivable bacteria associated with a sea anemone from coast of the Naozhou island in Zhanjiang, China]. Wei Sheng Wu Xue Bao 49, 246-250 (in Chinese).

Yumoto, I. (2007). Environmental and taxonomic biodiversities of Gram-positive alkaliphiles. In Physiology and Biochemistry of Extremophiles, pp. 295-310. Edited by C. Gerday \& N. Glansdorff. Washington, DC: American Society for Microbiology. 